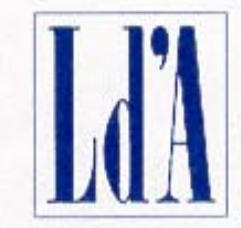

CENTRO STUDI LUCA D'AGLIANO

WWW.DAGLIANO.UNIMI.IT

\author{
CENTRO STUDI LUCA D'AGLIANO \\ DEVELOPMENT STUDIES WORKING PAPERS
}

N. 244

April 2008

\title{
The Impact of Material Offshoring on Employment in the Italian Manufacturing Industries: the Relevance of Intersectoral Effects
}

Simone Bertoli *

* IAB 


\title{
The impact of material offshoring on employment in the I talian manufacturing industries: the relevance of intersectoral effects ${ }^{1}$
}

\author{
Simone Bertoli
}

April 2008

\begin{abstract}
The lively media debate on the employment consequences of offshoring is not yet backed by an adequate empirical evidence around its actual effects. This paper relies on sectoral data to assess the impact of material offshoring on employment in the Italian manufacturing industries; with just one exception, sectoral-level analysis treat sectors as independent clusters of firms, while we introduce an index built on input-output data that captures the intersectoral spill-over effects of offshoring. The econometric analysis provides evidence that the direct effects of offshoring on employment are not significant once one allows for scale effects, while the intersectoral effects are negative and highly significant. This is consistent with the intuition that offshoring can lead to the disruption of domestic sub-contracting relationships, and that the adverse occupational consequences are not concentrated in the sectors that are directly involved in the offshoring process. Although such a finding should by no means regarded as supportive of a pessimistic perspective about the aggregate economic consequences of offshoring, it is nevertheless suggestive transitional costs can be substantial and diffuse.
\end{abstract}

\section{I ntroduction}

The impact of offshoring on employment is an issue that is often hotly debated in the media, and that has recently begun to attract an increasing interest among scholars. The Economist observes that the media "has tended to portray outsourcing-the contracting of once-core business functions to an outside supplier-and, in particular, its overseas component, offshoring, as a threat either to millions of jobs in Europe and America". ${ }^{3}$ Still, the existing empirical research has not yet produced a shared consensus about the consequences of offshoring on labour market outcomes, and further work is required in order to achieve a more solid-grounded understanding of this growing phenomenon.

The scope of this paper is to contribute to the empirical literature with an analysis of the impact of material offshoring on employment in Italy, using yearly input-output matrices disaggregated at the 2-digit ISIC classification code over the period 1995 to 2003, that were released by the ISTAT in 2006. The use of input-output data to build measures of offshoring dates back to the seminal

\footnotetext{
1 The author is grateful to Giorgia Giovannetti, Margherita Velucchi and Renato Paniccià for insightful discussions and helpful comments on earlier drafts of this paper, and to Theodora Xenogiani of the OECD Development Centre for providing access to the ANBERD data; the author gratefully acknowledges the financial support received from the FIRB project "International Fragmentation of Italian Firms. New Organizational Models and the Role of Information Technologies"; the usual disclaimers apply.
}

${ }^{2}$ IAB, Institut für Arbeitsmarkt- und Berufsforschung; address for correspondence: Weddigenstr. 20-22, D-90478 Nürnberg, Germnany; e-mail: simone.bertoli@iab.de

3 "Outsourcing: the evidence", The Economist, $30^{\text {th }}$ June 2005. 
contribution of Feenstra and Hanson (1996) and other recent studies have already employed input-output matrices that distinguish between domestically produced and imported intermediate goods (Amiti and Ekholm, 2006; Ekholm and Hakkala, 2006; Schöller, 2007a). Nevertheless, the data released by the ISTAT allow to move the analysis one step ahead, as the import matrix is not based on the "import proportionality assumption" that is employed by most countries (Bracci, 2006), an assumption that is likely to cast doubts on its actual informative content.

To the best of our knowledge, no empirical paper but Egger and Egger (2005) has explicitly analysed the sectoral interdependence of the labor market effects of offshoring, as sectors are rather treated as independent clusters of firms. Egger and Egger (2005) analyse how factor markets spread the effects of offshoring upon the demand for skilled and unskilled workers across sectors, as the delocalisation of labour-intensive phases of production alters the wage premium for skilled workers, and it thus induces other sectors to adjust their labour demand accordingly. We maintain that the analysis of the intersectoral effects of offshoring is critical to gain a full understanding of its occupational implications, and the innovative contribution of this paper resides in an alternative approach to such an analysis. More specifically, we are concerned with the impact of offshoring on subcontractors, as "often when large multinationals offshore certain activities [...] subcontracting firms may have to reduce their workforce" (OECD, 2007a). Such a concern could be of particular relevance for the case at hand as Falk and Wolfmayr (2005) observe that for Italy and other European countries "the growing importance of internationally sourced inputs is mainly the result of a substitution between formerly domestically sourced inputs and internationally purchased inputs rather than increased outsourcing per se." Drawing the data from input-output matrices, we propose a measure of the exposure of each sector to the employment consequences arising from the offshoring of other sectors. Interestingly, the possibility that offshoring may produce external effects has already been analysed by Costa and Ferri (2008 and 2005) and Federico and Minerva (2005) for the case of I taly using firms-level data, as both papers explored whether offshoring influences local employment.

We are aware that any assessment of the economic effects of the current phase of globalization, referred to as the great unbundling by Baldwin (2007), should be probably carried out at a finer level of disaggregation, but this paper represents just a first step towards a more detailed analysis, that will need to differentiate the impact of offshoring across skill levels of the workers - though Italian statistics are lacking in this respect - and then move towards the firms' level. Still, we maintain that this paper can provide relevant insights, as it suggests the opportunity to broaden the focus that - with a few exceptions - is adopted by this recent and fast-growing empirical literature. 
The paper is structured as follows: section 2 revises the elements of the economic literature on the impact of offshoring, and it provides a brief review of the analysis of the Italian experience in this respect. In section 3 we describe the analytical framework of the paper, revise the methodological issues involved in measuring the intensity of offshoring at the sectoral level and introduce the innovative contribution of this paper on the analysis of the intersectoral effects of offshoring; furthermore, we describe the sources of the data employed in the analysis and we present the relevant descriptive statistics. Section 4 contains the estimates obtained from the multivariate analysis, and the robustness tests that we conducted to address possible concerns about the sensitivity of the estimates with respect alternative definition of the relevant variables or alternative econometric techniques. Finally, section 5 draws the main conclusions of the paper.

\section{Review of the literature}

It is beyond the scope of this paper to provide a detailed review of the growing albeit still limited - empirical literature on the employment effects of offshoring, as thorough reviews of the methodological aspects of the analysis and of its core results have been recently provided by OECD (2007a) and Crinò (2007). We thus refer to these papers for a comprehensive overview of the literature, while we limit our focus here to those elements that have a specific relevance for our analysis. By the same token, we provide a brief review of the papers that have analyzed the possible implications of offshoring for the Italian economic system, as these could provide relevant insights for the analysis its impact on employment.

\subsection{Offshoring and employment}

Feenstra and Hanson (2003) argue that "trade in intermediate inputs can have an impact on wages and employment that is much greater than for trade in final consumer goods", as such an impact is not limited to the import-competing sectors, but it rather stretches out to all the sectors that use those inputs. The a priori expectation that is phrased in most papers is that the effect of offshoring on aggregate employment is ambiguous. Provided that offshoring decisions are driven by a cost-minimization objective, firms are most likely to transfer abroad the labor-intensive phases of production, and this gives rise to a negative impact on domestic employment. But such an adverse impact is matched by a positive effect that passes through an increase in output, as firms reap the gains from the restructuring of their production process after less productive phases have been 
offshored. ${ }^{4}$ The partial effect of offshoring for a given level of sectoral output is generally estimated through a conditional labor demand function, while the possible scale effect induced by offshoring can be accounted for with the estimation of an unconditional labor demand function, where the level of output is regarded as a choice variable of profit-maximizing firms. Thus, given the theoretical ambiguity, the assessment of the impact of offshoring on employment can be more profitably carried out on an empirical ground. But the literature has so far been characterized by a notable heterogeneity of empirical findings, that has so far prevented from either dismissing or validating the public concern about job losses.

Molnar et al. (2007) argue that "there is evidence for at least some countries and industries that outward investment has a significant negative association with the domestic demand for labour", but it is not possible to support generalized claims about the labor market effects of offshoring on the existing empirical evidence. With respect to the spatial dimension of the heterogeneity in the findings evidenced by Molnar et al. (2007), we can observe that Amiti and Ekholm (2006) suggest that this is connected to institutional differences across countries, as countries with rigid labor market regulations are more exposed to the occurrence of negative employment effects of offshoring. ${ }^{5}$ Although Amiti and Ekholm (2006) admit that the evidence they provide in support of their argument is fragile, this is indirectly corroborated by the conclusions of Falk and Wolfmayr (2005) and Schöller (2007a), who find a negative impact of offshoring on employment for European countries, ${ }^{6}$ and Schöller (2007a) explicitly traces back the estimated negative effects of offshoring to the strict labor market regulations prevailing in Germany.

On the other hand, the variability of the empirical evidence across industries could be attributed to different sectoral skill intensities; Falk and Wolfmayr (2005) observe that the negative effects on employment are confined to low skill industries, while skill intensive industries do not appear to reduce their labor demand once they offshore a part of their production activities. ${ }^{7}$ As Italy is characterized by strict labor market regulations, ${ }^{8}$ and its sectoral distribution of production is skewed towards less skilled sectors, the arguments advanced to

\footnotetext{
4 For instance, OECD (2007b) argues "a priori, offshoring should have a negative effect on the labour-intensity in an industry (the 'technology effect'), but a positive effect on the level of output, due to the productivity gains from offshoring (the 'scale effect')" and Amiti and Wei (2005) observe that "offshoring may have a positive or negative effect on employment depending on whether the scale effect outweighs the negative substitution and productivity effects."

5 Similarly, Molnar et al. (2007) argue that "if there are significant labour market rigidities, or institutional features such as binding floors for the wages of less skilled workers, then it becomes more likely that there will be a greater quantitative effect on aggregate employment".

6 The sample of countries analyzed by Falk and Wolfmayr (2005) includes Austria, Denmark, Finland, Germany, Italy, the Netherlands and Sweden, while Schöller (2007a) focuses on Germany alone.

7 I MF (2007) introduces a similar distinction between skilled and unskilled sectors when analyzing the impact of offshoring upon the labor share.

${ }^{8}$ See Botero et al. (2004); OECD (2004) observes that Italy has significantly reduced the rigidity of its labor market regulations since the late 1980s, although they remain stricter than the OECD norm.
} 
interpret the heterogeneity of findings strengthen the presumption that offshoring by I talian firms could be negatively affecting domestic employment.

Although sectoral and geographical variability are important, there are further (methodological) reasons that can help to explain the heterogeneity of findings in the in the empirical literature on offshoring.

The single most relevant one is probably due to the fact that offshoring is an elusive concept, that poses severe definitional and measurement problems, that have been addressed in a variety of ways. OECD (2007a) provides a detailed description of the possible definitions of offshoring, and in the appendix we review the alternative approaches that have been proposed to measure it with sectoral data. The basic rationale behind these indices is to estimate the share of intermediate inputs - either manufacturing goods or services - that each sector imports from abroad; the focus of these indices is either restricted to the inputs purchased from the same sector or broadened to include all intermediate inputs, and these measures are then scaled by some measure of sectoral dimension, such as total input costs, output or value added. Early studies, like the seminal contribution by Feenstra and Hanson (1996), lacked access to direct information on imported inputs, so they had to introduce restrictive hypothesis about the import-content of intermediate inputs to compute the sectoral measures of offshoring. Later studies, as Amiti and Ekholm (2006) and Schöller (2007b), instead rely on direct information on imported inputs, although Bracci (2006) warns against the limited informational content of the data published by most OECD countries, with Italy representing a welcome exception in this respect (Bracci et al., 2006). ${ }^{9}$ In interpreting her finding of a negative impact of service offshoring on employment in Germany, Schöller (2007a) argues that "the underlying cause for the domestic employment reduction [...] is not offshoring, but high labor costs", so that "offshoring then is rather a symptom than a cause of domestic labor market problems". By the same token, Egger and Egger (2005) observe that "since factor market conditions are usually considered to be a key determinant of international outsourcing decisions, factor market adjustments should give rise to feedback effects on foreign sourcing". Both these quotes strongly argue against the treatment of offshoring as exogenous to the prevailing labor market conditions, and this represents a key analytical challenge; the alternative approaches to the endogeneity of offshoring ranges from its explicit instrumentation, an approach that is highly data demanding (Amiti and Wei, 2005; OECD, 2007b), through the adoption of dynamic panel estimators (Egger and Egger, 2005; Schöller, 2007b)

\footnotetext{
9 As several studies (e.g. Schöller, 2007b; Daveri and Jona-Lasinio, 2007) suggest that alternative indices can produce radically different pictures of the level and of the dynamics of sectoral offshoring, this calls for a robustness checks of any estimated effects against alternative measures of offshoring and for the adoption of estimation techniques that are (relatively) less sensitive to the presence of measurement errors.
} 
and to the questionable treatment of offshoring as an exogenous variable (Falk and Wolfmayr, 2005).

An additional issue that needs to be addressed is that offshoring can be expected to correlate with sectoral productivity; this is likely to play a key role in the internationalization decision (e.g. Helpman et al., 2004; Castellani and Zanfei, 2006), with more productive firms self-selecting themselves into deeper forms of internationalization. This entails that one may wrongly attribute to offshoring some effects that are actually due to the factors that simultaneously affect the decision to move some of the phases of production abroad and domestic employment.

\subsection{Analysis on the effects of offshoring in I taly}

In this paragraph, we provide a revision of the empirical papers that have dealt with the economic impact of offshoring in Italy, broadening the focus beyond the employment effects, and revising also those papers that employed firm-level rather than sectoral data. ${ }^{10}$

Two of these papers, namely Daveri and Jona-Lasinio (2007) and Barba Navaretti et al. (2007), analyze the impact of offshoring on productivity, using the ISTAT input-output data and the REPRINT firm-level dataset respectively. The estimates produced by Daveri and Jona-Lasinio (2007) with both OLS and IV suggest that material offshoring positively influences productivity, measured as the growth rate of value added per full-time equivalent worker. Conversely, service offshoring has a dubious, or even negative impact, on productivity growth, a prima facie puzzling finding that the authors observe has already been found for other European countries.

The evidence provided by Daveri and Jona-Lasinio (2007) on sectoral data is consistent with the firms-level analysis conducted by Barba Navaretti et al. (2007); Barba Navaretti et al. (2007) rely on the propensity score matching technique to select a proper control group of firms that have not invested abroad, to derive a measure of the impact of offshoring on performance at home that is not biased by the likely non-random self-selection of firms into the two groups. The authors distinguish between cost-oriented, vertical and market-seeking horizontal investments, as it is the first type of offshoring, usually directed towards LDCS, that usually attracts the greatest pubic concern. Barba Navaretti et al. (2007) dismiss the fears about an adverse impact of offshoring, as "there is no evidence of a negative effect of outward investments to cheap labour countries, [as] they

\footnotetext{
10 The only two papers that we referred to in the previous paragraph and that studied Italian data are Falk and Wolfmayr (2005) and Amiti and Ekholm (2006); these are not revised in detail here as the former realized pooled estimates with data from six other European countries, while Amiti and Ekholm (2006) based their evidence on a cross-section of only 14 observations.
} 
enhance the efficiency of home activities, with also positive long term effect on output and employment growth."

Castellani et al. (2006) also draw their data from REPRINT dataset, combined with the data from the Osservatorio sui bilanci delle società di capitale and the Excelsior dataset, both released by the Italian Union of Chambers of Commerce. The focus of this paper is to understand whether investing abroad depresses aggregate employment, and whether the firms that invest abroad engage in a skill upgrading, increasing their share of skilled workers. The issue of the non random selection of MNES is dealt with by the use of Arellano and Bond (1991) dynamic panel estimators, and the authors differentiate with respect to the destination of the investment abroad. The findings are consistent with the evidence by Barba Navaretti et al. (2007), as no adverse impact is found on aggregate employment, while the evidence suggests that investing abroad may be conducive to skill upgrading, although the limitations of the Italian data in this respect force the authors to identify skilled workers with white collars.

While neither Castellani et al. (2006) nor Navaretti et al. (2007) find any evidence of an adverse impact of investing abroad on domestic employment, both analysis focus exclusively on the direct effects upon the firms that undertake these investments. As we argued in the introduction, this may not be fully satisfactory, as investing abroad or offshoring could determine significant external effects. A broader focus is adopted by Federico and Minerva (2005) and Costa and Ferri (2005), who analyze how offshoring influences the dynamics of local employment. Federico and Minerva (2005) argue that "home local suppliers and home local labor market are likely to be influenced through market and non-market interactions descending from outward FDI". They test the relevance of their argument using data from the Ufficio Italiano Cambi, that provide information about the industry and local area of origin of FDI, that are matched with firm-level data from the ISTAT; the data refer to 12 manufacturing sectors and 103 local administrative areas over the period 1996-2001. Their analysis provides little support to the public fears of job losses, as "the employment performance of local areas doing more FDI towards advanced economies appears to be better than industry average", while "the evidence suggesting a negative impact of FDI towards developing countries is weak" (Federico and Minerva, 2005). Thus, the extension of the analysis to include possible external effects FDI by Federico and Minerva (2005) provides evidence that is consistent with the findings that emerge from Castellani et al. (2006) and Navaretti et al. (2007), who apply the usual narrower focus to the direct effects of offshoring.

Costa and Ferri (2008 and 2005) move their analysis from an intuition that is similar to the one by Federico and Minerva (2005), as they argue that "since Italy's 
productive sector consists primarily of a myriad of networked small and medium-sized enterprises, considering only the employment performance of [offshoring] firms per se appears incomplete, if not potentially misleading". The authors draw their data from an ISAE survey, and the multivariate analysis indeed suggests that offshoring tends to produce adverse indirect effect on employment. This is an interesting insight, although the model estimated by Costa and Ferri (2005) suffers from a poor goodness of fit, and it might be exposed to a spurious causality, as offshoring and a shrinking employment could be simultaneous responses by declining areas and sectors. Nevertheless, the insights from Costa and Ferri (2008 and 2005) and Federico and Minerva (2005) strengthen the argument for an analysis of the indirect effect of offshoring, that they analyze through firms' geographical proximity, while we will attempt to provide a more direct measure of subcontracting relationships.

\section{Analytical framework}

\subsection{Sectoral measures of offshoring - direct and external effects}

The scope of this paper resides in the analysis of the impact of material offshoring on employment levels in manufacturing industries in Italy, and we thus need to define an index of material offshoring. We draw our data from the input-output matrices disaggregated at the 2-digit ISIC level published by the ISTAT the period 1995 to 2003. This set of matrices contain information on the sectoral distribution of both domestically produced and imported inputs, and the latter are imputed across sectors using the methodology described by Bracci et al. (2006) that markedly improve from the usual "import proportionality assumption". We adopt a slight variation of the one defined in [a3] in the appendix and adopted by Bracci (2006), Amiti and Ekholm (2006) and Schöller (2007a), as we divide the total costs for imported manufactured goods by the total costs of manufactured inputs. Using the notation described in the appendix, for the $\mathrm{i}$-th sector at time $\mathrm{t}$, the index of material offshoring is computed as

$\mathrm{o}_{\mathrm{ti}}^{\mathrm{m}}=\sum_{\mathrm{j}=1}^{\mathrm{m}} \mathrm{f}_{\mathrm{tij}} / \sum_{\mathrm{j}=1}^{\mathrm{m}} \mathrm{a}_{\mathrm{tij}}$ 
where $f_{\mathrm{tij}}$ and $\mathrm{a}_{\mathrm{tij}}$ are drawn from the input-output matrices for imported and total goods respectively. ${ }^{11}$ We also employ a narrower definition - described in [a4] and adopted by Egger and Egger (2005) and Bracci (2006) - to test the robustness of our estimates.

As the fragmented structure of the Italian manufacturing system suggests that offshoring is likely to determine significant external effects, ${ }^{12}$ an analysis that focuses on the direct effect of material offshoring alone would be unsatisfactory, as it would miss any effect that occurs outside the sector that decides to move intermediate stages of its production process abroad.

To pin down ideas, think about a footwear factory that moves its production abroad, and that decides to terminate the contract with the local subcontractor that produced rubber soles for its shoes; or, imagine that the local producer of rubber soles is an affiliate of the footwear industry, that decides to close its affiliate and purchase the soles from a foreign producer. In both these examples, the decision to move abroad the core production process or to replace as domestic subcontractor with a foreign one is taken in a sector, but the (adverse) employment effects of such a decision are partly - if not entirely - felt in a second sector.

However, a neglect of the sectoral interdependence we just described is common in the literature on offshoring, as all the papers that analyze its labor market effects at the sectoral level - but Egger and Egger (2005) - treat each sector as a cluster of firms that has no interaction with the other clusters. Egger and Egger (2005) argue that the neglect of sectoral interdependence represents a major analytical shortcoming: if offshoring by a given sector does influence the employment level and the wages prevailing in that sector, then this should influence other sectors via the labor market; similarly, if offshoring determines significant scale effects, these could be expected to influence other sectors via the market for intermediate goods. The authors explicitly consider sectoral interdependence via the intermediate goods market including among the regressors a weighted transformation of the dependent variable; this variable, for the $\mathrm{j}$-th sector, is equal to the mean value of the dependent variables of the other sectors, with (time-invariant) weights given by the respective demands for intermediate uses of the goods produced by the $\mathrm{j}$-th sector. ${ }^{13}$ The coefficient of this variable captures the intersectoral spill-overs, and the analysis by Egger and Egger (2005) about the impact of offshoring by Austrian firms on the sectoral ratios of skilled to unskilled workers suggest that "indirect spillover effects account for about two-thirds of the estimated employment effects".

${ }^{11}$ We are aware that this kind of measures fails to capture "the situations where the final stages of production [...] are offshored abroad" (Ekholm and Hakkala, 2006).

12 "Effetto filiera" by G. Ferri and S. Costa, published on lavoce.info, $19^{\text {th }}$ November 2007.

${ }^{13}$ Formally, such a transformation is obtained pre-multiplying the vector of the dependent variable by a (time-invariant) input-output matrix, where the diagonal elements have been replaced by zero and each element is normalized by the row sum; Egger and Egger (2005) also substitute the input-output matrix by a matrix that describes the flows of workers across sectors. 
We draw on the approach proposed by Egger and Egger (2005) to assess the possible impact of offshoring on subcontractors, but we introduce two major departures from the original analysis. We rely on input-output data to define a measure of the exposure of each sector to the offshoring decisions taken by the other sectors. ISTAT data allow us with time-varying measures of the intensity of sectoral linkages, and this represents the first departure from Egger and Egger (2005), who apply the 1995 Austrian input-output matrix for the whole 1990-98 period. Second, and more fundamentally, we argue that the sectors whose goods are mostly used as intermediate rather than final consumer goods are more exposed to the occurrence of intersectoral spill-overs; this entails that one should introduce sectoral weights that are coherent with this plausible hypothesis, while Egger and Egger (2005) rely on weights that are not sensitive to the relevance of the intermediate uses of the goods produced by the $\mathrm{j}$-th sector in the total demand for those goods.

To introduce the index that is meant to capture the exposure of each manufacturing sector to the consequences of offshoring by the other sectors, first consider the measure defined in [2] for the i-th sector:

$o_{t j i}^{m}= \begin{cases}\frac{f_{t i j}}{a_{t i j}} & \text { for } j=1, \ldots, m \text { and } j \neq i \\ 0 & \text { otherwise }\end{cases}$

This is equal to the share of imported inputs from the $\mathrm{i}$-th sector over the total intermediate use of the same goods by the $j$-th sector; this index reflects the extent to which any sector $\mathrm{j}$ relies on foreign produced goods to cover its demand of the intermediate goods produced by the $\mathrm{i}$-th sector.

This index is intuitively closer to the second example of the external effects of offshoring we provided above, while it may appear unfit to capture the first type of intersectoral spill-overs; still, we argue that this inadequacy is not different from the one that affects traditional measures of offshoring, that by the same token fail to capture the cases where an industry moves its entire production abroad and then imports to the home country its goods for final consumption.

The index defined in [2] needs to be averaged across all the sectors that use the goods produced by the $\mathrm{i}$-th sector, to derive the full measure of the exposure of this sector to the possible (adverse) external effects of offshoring on employment. As we argued, the weight attributed to the $\mathrm{j}$-th sector needs to reflect the relevance of demand for the goods produced by the i-th sector in the total demand for these goods rather than for their total intermediate uses; thus, we define the index of exposure to the external effects of material offshoring as: 
$o_{\mathrm{ti}}^{m, e}=\left(\sum_{j=1}^{m} o_{t i j}^{m} \frac{a_{t i j}}{y_{t i}}\right)$

where $\mathrm{y}_{\mathrm{ti}}$ represents the demand for the goods produced by the $\mathrm{i}$-th sector at time t. Observe that we are turning input-output matrices around, as the summation in [3] is conducted along the rows of the matrix, while all the indices employed in the literature look at the data along columns. The index defined in [3] is higher i) the higher the share of intermediate uses share in the total demand for the goods $\mathrm{i}$-th sector, ii) the higher the reliance by the other sectors on foreign suppliers to purchase the goods produced by the i-th sector. For brevity's sake, we refer to the index defined above as the index of external offshoring, although this is just a shorthand expression for the index of exposure to the external effects of material offshoring.

\subsection{Set up of the analysis}

The two indices that we defined in [1] and [3] are meant to capture two distinct effects of offshoring upon sectoral employment, as the first one is (a slight variation of) the usual broad measure of offshoring that is meant to capture its direct effects, while the second represents the innovative contribution of this paper, as it should capture the exposure of a sector to the indirect effects.

In line with the empirical literature, we assess the impact of offshoring upon sectoral employment via the estimation of a labor demand function. As we observed in section 2, the usual expectation is that the direct effect of offshoring should be negative once the estimates control for sectoral output, while the effect becomes ambiguous and may thus change its direction once one lets the scale effects to come into play.

The a priori expectations about the external impact of offshoring are markedly different, as the scale effects here exert an opposite influence on the sectoral labor demand; offshoring by other sectors should produce no effect when one conditions on sectoral output, as this entails that a sector is facing a change in the composition, but not in the level, of its aggregate demand. Conversely, if one does not control for the level of sectoral output, the indirect effect can be expected to exert a negative influence on employment, as a higher reliance of other sectors on foreign produced intermediate goods entails a fall in the aggregate demand a sector faces, because of the break of the domestic subcontracting chains. Formally, we expect the coefficient of $\mathrm{o}_{\mathrm{ti}}^{\mathrm{m}, \mathrm{e}}$ to be not significant in the estimation of the conditional 
labor demand function, while it should be negative once we estimate an unconditional labor demand function.

We adopt the following log-linear specifications of the conditional and unconditional labor demand functions, that we will estimate once the variables are transformed in first differences: ${ }^{14}$

$$
\begin{aligned}
& \ln \left(\mathrm{e}_{\mathrm{ti}}\right)=f\left(\ln \left(\mathrm{w}_{\mathrm{ti}}\right), \ln \left(\mathrm{q}_{\mathrm{ti}}\right), \ln \left(\mathrm{k}_{\mathrm{ti}}\right), \ln \left(\mathrm{rd}_{\mathrm{ti}}\right), \ln \left(\mathrm{o}_{\mathrm{ti}}^{\mathrm{m}}\right), \ln \left(\mathrm{o}_{\mathrm{ti}}^{\mathrm{m}, \mathrm{e}}\right), \ln \left(\mathrm{imp}_{\mathrm{ti}}\right)\right) \\
& \ln \left(\mathrm{e}_{\mathrm{ti}}\right)=f\left(\ln \left(\mathrm{w}_{\mathrm{ti}}\right), \ln \left(\mathrm{p}_{\mathrm{ti}}\right), \ln \left(\mathrm{k}_{\mathrm{ti}}\right), \ln \left(\mathrm{rd}_{\mathrm{ti}}\right), \ln \left(\mathrm{o}_{\mathrm{ti}}^{\mathrm{m}}\right), \ln \left(\mathrm{o}_{\mathrm{ti}}^{\mathrm{m}, \mathrm{e}}\right), \ln \left(\mathrm{imp}_{\mathrm{ti}}\right)\right)
\end{aligned}
$$

While a formal definition of the variables - and of the respective data sources - is provided in Table $1,{ }^{15}$ we describe here the rationale for the choice of the set of regressors, and the expectations about their impacts on employment.

The wage $w_{i t}$, that is deflated with an index of the prices of intermediate goods defined as in OECD (2007b), is clearly expected to be a major determinant of sectoral employment, and it should be clearly negatively related to it. The level of real sectoral demand $q_{i t}$ should positively influence employment in the conditional labor demand function, while the literature contains no clear expectation about the effect of the index of sectoral prices $p_{i t}$ that substitutes for $q_{i t}$ in the unconditional labor demand, and the estimated effects are heterogeneous, both across studies and across specifications in the same paper.

The measure of the real capital stock $k_{\text {it }}$ is expected to positively influence sectoral employment.

Following the literature, we also introduce a measure $\mathrm{rd}_{\mathrm{it}}$ of the expenditure research and development among the regressors, as more productive and innovative sectors can be expected to have a greater propensity to offshore, so that a failure to control for this likely factor would result in a biased estimate of the coefficients of interest. However, little reflection is paid to the fact that the relationship between $R \& D$ expenditures and sectoral employment is ambiguous. $R \& D$ expenditures can be related to either process or product innovations, that have "contrasting employment effects: increasing productivity and replacing labour in the case of process innovations; creating new markets, production and jobs in the case of product innovations", as Antonucci and Pianta (2002) observe. One could argue that process innovation is more closely related than product innovation to the formation of new capital stock, as the former type of innovation requires the

\footnotetext{
${ }^{14}$ Note that the labor demand functions in [4] describe a relationship between employment and the contemporary values of the independent variables, so that we do not allow for lagged effect of offshoring on employment; this choice is driven by the limited dimension of our panel of data, a feature that is common in the literature and that unfortunately severely limits the possible analytical choices.

${ }^{15}$ Note that we consider the growth rate of the measures of offshoring, as in OECD (2007b), while most of the literature relies instead on the difference; we will test the robustness of our estimates against this alternative specification.
} 
introduction of new machinery and productive equipment in which it is embedded. Thus, we propose to interact the measure of $R \& D$ intensity with the one representing the capital stock: in line with the argument by Antonucci and Pianta (2002), the expectation is that the coefficient of measure of $R \& D$ should be positive, capturing the effects of product innovation, while the coefficient of the interacted variable should have a negative sign as it reflects the introduction of labor-saving process innovations.

We have already expressed the expectations about our two variables of interest, $o_{t i}^{m}$ and $o_{t i}^{m, e}$, but we still need to observe that the latter can be re-formulated as follows:

$\mathrm{O}_{\mathrm{ti}}^{\mathrm{m}, \mathrm{e}}=\frac{\left(\sum_{\mathrm{j}=1}^{\mathrm{m}} \mathrm{f}_{\mathrm{tji}}\right)-\mathrm{f}_{\mathrm{tii}}}{\mathrm{y}_{\mathrm{ti}}}$

so that for the i-th sector it is equal to the sum of the imports of the goods of the same sector by the other manufacturing sectors over the total demand the $i$-th sector faces. As Feenstra and Hanson (2003) argue that trade in intermediate goods has more pervasive effects than trade in final consumer goods, this hypothesis can be tested introducing through the inclusion among the regressors of a variable $\mathrm{imp}_{\mathrm{ti}}$ that is defined as the ratio between the imports of goods produced by the i-th sector, over the total demand faced by the same sector. The argument by Feenstra and Hanson (2003) suggests that this latter variable should have a weaker impact on sectoral employment than the one that we expect from the offshoring decisions of the other sectors.

\subsection{Descriptive statistics}

Some of the other sources we draw our data from are not available at the level of sectoral detail of the ISTAT input-output matrices. It was thus necessary to aggregate some of the 2-digit ISIC sectors in order to combine input-output data with the OECD STAN and ANBERD databases, and with the National Accounts published by the ISTAT itself. Table 2 describes the final level of sectoral aggregation at which the analysis is conducted: we have 14 unit of analysis, seven of which correspond to a 2-digit ISIC sector while seven result from the aggregation of at least two sectors. ${ }^{16}$ The choice of the level of aggregation could have a bearing on the analysis, as Amiti and Wei (2005) argue that a negative direct impact of

${ }^{16}$ For convenience's sake, we nevertheless refer to our units of analysis as sectors, although such a definition is not strictly correct. 
offshoring on employment can be detected only at a very fine level of sectoral disaggregation, while at a more aggregate level there might be a "sufficient growth in demand in other industries within these broadly defined classifications to offset any negative effects".

Figures 1a-1n report the sector-specific evolution between 1995 and 2003 of the three measures of offshoring - broad, narrow and external; a visual inspection of the figures reveals immediately that the broad and narrow measure of offshoring may differ in level, with the sign of the difference between the two measures varying across sectors, but the two lines run parallel to each other. This entails that the choice between these two measures of offshoring is likely to be immaterial, as little differences can be expected to arise in the multivariate analysis from the inclusion of either the broad or narrow index.

Consistently with Bracci (2006) and Daveri and Jona-Lasinio (2007) who employ the same ISTAT input-output data, there is a significant variability across sectors both in the level and in the evolution of the broad and narrow measure of offshoring, as one can read from Table 3. With respect to broad offshoring, there are five sectors - including chemicals, mechanical and automotive industry - that over the period import from abroad more than 50 percent of their material inputs; over the same period, though, the sectors that recorded the fastest-growing offshoring are textile, textile products, footwear and furniture industries, while four sectors recorded a decline in their respective indices of broad offshoring.

Visual inspections of the Figures $1 a-1 n$ and the descriptive statistics reported in Table 3 reveal that the measure of offshoring that we define as external does not follow a pattern that is close to the one of the usual broad and narrow measures of offshoring. Rubber and plastic products is the sector with the highest exposure to the external effects of offshoring, while the sectors that recorded the fastest growth of such an exposure are those producing wood and wood products, pulp and paper, coke and refined petroleum and metal and fabricated metal products. Not surprisingly given the definition we provided, intermediate uses represents a sizeable share of the demand for the goods produced by these sectors, that expose them to the consequences of offshoring decision taken elsewhere.

Table 3 also contains the growth rates over the reference period of the variables that are included in the analysis - and their average level between 1995 and 2003 when this is informative.

Table 4 reports the matrix of correlations among the variables included in the analysis, to obtain a first rough picture of the relationships with the dependent variable, and of possible problems of multicollinearity among the regressors. While the first data column in Table 4 evidences that most the sign of the bivariate relationship between employment and the independent variables is consistent with 
our expectations, this is not the most interesting insight that can be drawn from the correlation matrix. What is remarkable, instead, is that the broad and the external measures of offshoring display remarkably different correlations with sectoral output, expressed in real terms. The real growth rate of sectoral output has a correlation with the growth rate of broad offshoring equal to 0.47 , while the correlation with external offshoring is -0.67 , with both coefficients being significant at the 1 percent confidence level. This is consistent with the hypothesis that offshoring can give rise to positive scale effects, while the sectors that are exposed to the offshoring by other sectors suffer from a significant fall in the aggregate demand they face. This strongly suggests that the two variables are likely to exert an opposite effect on sectoral employment once we estimate an unconditional labor demand.

Furthermore, broad and external offshoring display opposite correlations with the interaction between capital formation and $R \& D$ expenditures, a variable that we introduced as a proxy of process innovation. While broad offshoring has a correlation of 0.38 with this interacted variable, external offshoring displays a correlation of -0.28 , and both coefficients are significantly different from zero. Provided that this interacted variable captures process innovation, it is tempting to argue about the relationship between innovation and offshoring, abstracting from the direction of an eventual causal relationship. Consistently with most theoretical modelling and empirical evidence, one could argue that innovative sectors are more likely to offshore; ${ }^{17}$ similarly, one could infer that the sectors that offshore, then restructure their production processes, expanding the scale of their production - as Table 4 indeed suggests - thanks to the productivity gains ensuing from process innovation. Conversely, one could argue that the sectors which fail to innovate are more exposed to the risk of loosing their domestic industrial clients, who shift their demand towards foreign suppliers of intermediate goods, although these speculations are admittedly tentative.

\section{Multivariate analysis}

The literature on the employment effects of offshoring contains several warns about the econometric issues that need to be addressed in order to provide a solid-grounded estimation of labor demand functions. Although the opportunity to properly address these concerns, though, is severely limited by the dimension of

${ }^{17}$ The correlation between $R \& D$ expenditures and broad offshoring is 0.17 , significant at the 10 percent confidence level. 
the panel, in what follows we will describe how we have attempted to tackle these serious analytical issues.

The first six data columns in Table 5 report alternative estimations of the conditional labor demand functions described in [4], while the other six data columns report the corresponding estimations of the unconditional labor demand, where a measure of sectoral prices replaces the variable that described real sectoral output. ${ }^{18}$ These two sets of estimates differ only in this respect, while they display no differences with respect to the other regressors nor with respect to the econometric techniques that we employed. Both labor demand functions are initially estimated on first-differenced variables as a two-way error component model, i.e. the error term of the model contains both a time and a sector-specific component. The standard errors are derived with the option cluster robust in Stata 9.2, to control for possible heteroskedasticity and intra-cluster correlation, as suggested by Schöller (2007a). ${ }^{19}$ Secondly, following Amiti and Wei (2005) and Falk and Wolfmayr (2005), we estimate of the conditional and unconditional labor demand functions through the Stata command rreg, that implement an iterative, weighted procedure that prevents eventual outliers in the series o drive the estimates obtained from a panel of limited dimension. To provide a fuller treatment of the likely heteroskedasticity induced by the panel structure - as manufacturing sectors are of greatly varying scales - and for possible serial correlation of the residuals, we resort to feasible generalized least squares, FGLS, panel estimators. Furthermore, as the - either direct or indirect - effects of offshoring need not to be instantaneous, we also included the lagged values of the two first-differenced measures of offshoring, and we tested the null hypothesis that the contemporaneous and lagged coefficients sum up to zero. Finally, as the variables of interest are admittedly measured with error, given the fuzziness of the concept of offshoring and that this could bias the results (OECD, 2007b; Amiti and Wei, 2005), we re-estimated the labor demand functions taking 2- instead of 1-year differenced variables.

The estimations of the conditional labor demand functions suggest that broad material offshoring exerts a negative, albeit small and of varying statistical significance, impact on employment, as conditioning on the level of sectoral output does not allow scale effects to come into play. A 1 percent increase in broad offshoring reduces by approximately 0.04 percentage points the growth rate of sectoral employment. Conversely, external offshoring exerts no significant influence

\footnotetext{
${ }^{18}$ All the results that we present below are robust to the inclusion of a narrow instead of the chosen broad measure of offshoring; the results are available upon request from the author.

${ }^{19}$ To further limit the heteroskedasticity of the panel, we have excluded from the multivariate analysis the coke and petroleum refinement sector (ISIC code 23), as the sector has approximately 25,000 employees over the reference period, well below the levels of the other sectors.
} 
upon employment, as the positive estimated coefficient is just marginally statistically significant in specifications (2) and (6) only.

The estimates obtained with iterative estimation techniques, i.e. specification (2) show little variations from alternative specifications, so that outliers do not appear to be an issue in this case, while elsewhere, e.g. Schöller (2007a), the coefficients of the variables of interest proved to be sensitive to the exclusion of outlying sectors. Moreover, comparing specifications (3) and (4) that differ only with respect to the hypothesis about the correlation structure of the residuals - as in (3) the assumed $\mathrm{AR}(1)$ process is allowed to be sector-specific - we can argue that we can safely restrict the process of serial correlation in the residual to be invariant across sectors.

It can be observed that the estimation of the conditional labor demand function evidences an interesting relationship between capital formation, the expenditure in $R \& D$ and the growth of sectoral employment, and similar - and even stronger arguments apply to the estimation of the unconditional labor demand function. The coefficient of R\&D is positive, while its interaction with the formation of capital stock is negative, and both are highly significant - except for the interaction term when taking 2-year differenced variables. These estimates are consistent with the intuition that the interaction between the two variables allows to better describe the relationship between employment and innovation, differentiating between process and product innovation.

The other columns in Table 5 contain alternative estimations of the unconditional labor demand function, where the real growth rate of output is replaced by a sectoral price measure, that corresponds to the implicit deflator of the value added. As expected and in line with the evidence provided by OECD (2007b), ${ }^{20}$ once scale effects come into play, the adverse direct impact of offshoring upon employment disappears, as the coefficient of broad offshoring looses any statistical significance. More interestingly, the measure of external offshoring exerts a negative and highly significant influence on employment growth: the estimated elasticity between share of imported goods by other sectors over sectoral demand and sectoral employment ranges between -0.11 and -0.18 . Most notably, although taking 2 -year differenced variables clearly lowers the overall goodness of fit of the model, the coefficient of the external measure of offshoring remains significant at the 1 percent confidence level. Furthermore, when include in the regression also the lagged value of the variable of interest, we obtain an insignificant coefficient for the lagged value and both the Wald and the LR test reject at the 1 percent confidence level the null

20 "The conditional demand estimates indicate that there is a significant negative correlation between offshoring whitin the same industry (narrow offshoring) and labour-intensity (employment at given output). [...] The unconditional labour demand estimates do not indicate any impact of narrow offshoring on the level of sectoral employment, once the scale effect is taken into account", OECD (2007b). 
hypothesis that the sum of the contemporaneous and lagged effect of external offshoring is equal to zero.

Consistently with the arguments put forwards by Feenstra and Hanson (2003), the employment effect of the imports of intermediate goods is remarkably different from those due to the import of final consumer goods, as the coefficient of the share of imports for final consumption in sectoral demand is smaller in size at best significant at the 10 percent confidence level - specification (7) and (12). This sharp contrast would not emerge if one focused only on the direct effects of offshoring - that are similarly non significant in the unconditional labor demand function - but the picture changes once one recognizes that significant effects can occur outside the sectors that move part of their production abroad. The broadening of the focus on the employment effects of offshoring thus questions the argument by Molnar et al. (2007), who observe that "the findings from existing studies [...] provide few reasons for suggesting that the aggregate employment effects of international sourcing and outward investment differ greatly from the general effects of international trade".

\section{Conclusions}

Offshoring can give rise to significant productivity gains through the restructuring of the production process it induces, but it can also impose relevant adjustment costs, though these may be most pronounced outside the offshoring sectors themselves. The analysis that we conducted on a panel of sectoral-level data for the Italian manufacturing industries shows that employment dynamics in a given sector are influenced by the offshoring decisions of the sectors that use its products as intermediate inputs in their own production processes. This finding is consistent with the intuition - recently analysed using firm-level data by Costa and Ferri (2008) - that offshoring can lead to the disruption of domestic sub-contracting relationships. This entails that the adverse occupational consequences of offshoring can affect the whole set of manufacturing industries, rather than being concentrated in the sectors that are directly involved in the offshoring process.

Such a finding should by no means regarded as being supportive of a pessimistic perspective about the aggregate economic consequences of offshoring, but it is nevertheless suggestive transitional costs can be substantial, and widespread. This would call for an adequate system of workers' protection to shelter them from bearing the brunt of the process of adjustment and restructuring. 


\section{References}

Amiti, M. and K. Ekholm (2006), "The Effect of Offshoring on Employment in Rigid Labor Markets: Evidence from EU Countries", I MF Working Paper.

Amiti, M. and S-J. Wei (2005), "Service Offshoring, Productivity, and Employment: Evidence from the United States", I MF Working paper No. 05/238.

Antonucci, T. and M. Pianta (2002), "Employment Effects of Product and Process Innovation in Europe", in International Review of Applied Economics, Vol. 16, No. 3, pp. 295-307.

Arellano, M. and S. Bond (1991), "Some Tests of Specification for Panel Data: Monte Carlo Evidence and an Application to Employment Equations", in The Review of Economic Studies, Vol. 58, No. 2, pp. 277-97.

Baldwin, R. (2007), "Globalizzazione, la sfida dell'unbundling", in Come sta cambiando l'Italia, Baldwin, G. Barba Navaretti and T. Boeri (eds), il Mulino.

Barba Navaretti, G., D. Castellani and A-C. Disdier (2007), “How Does Investing in Cheap Labour Countries Affect Performance at Home? France and Italy", paper presented at the Meeting of Experts on "FDI, Technology and Competitiveness", UNCTAD, Geneva, 8-9 March.

Botero, J., S. Djankov, R. La Porta, F. Lopez-de-Silanes, and A. Shleifer (2004), "The Regulation of Labor", in Quarterly Journal of Economics, Vol. 119, pp. 1339-82.

Bracci, L. (2006), “Una misura della delocalizzazione internzionale”, in Rapporto ICE 2005-2006, pp. 231-8.

Bracci, L., R. Astolfi e A. Giordano (2006), “La rappresentazione delle importazioni per settore di attività economica e di utilizzazione", paper prepared for the conference "La revisione generale dei conti nazionali del 2005", Rome, 21-22 June.

Castellani, D. and A. Zanfei (2006), Multinational Firms, Innovation and Productivity, Edward Elgar.

Castellani, D., I. Mariotti and L. Piscitello (2006), "Outward investments and skill upgrading. Evidence from the Italian case", Working Paper No. 185, Centro di Ricerca sui Processi di Innovazione e Internazionalizzazione.

Costa, S. and G. Ferri (2008), "Firing and Subcontractors? Spillover Employment Effects of Offshoring in Italy", Development Studies Working Paper No. 238, Centro Studi Luca D’Agliano.

Costa, S. and G. Ferri (2005), "The determinants and employment effects of international outsourcing: the case of Italy", Southern Europe Research in Economic Studies Working Paper no. 16, University of Bari.

Crinò, R. (2007), "Offshoring, Multinationals and Labor Market: A Review of the Empirical Literature", Working Paper No. 196, Centro di Ricerca sui Processi di Innovazione e Internazionalizzazione.

Daveri, F., M. Iommi and C. Jona-Lasinio (2006), "Quantifying the productivity counterpart of outsourcing in the Italian manufacturing industries", paper prepared for the OECD Productivity Workshop, Bern, 16-18 October.

Daveri, F. and C. Jona-Lasinio (2007), "Off-shoring and productivity growth in the Italian manufacturing industries", LLEE Working Document no. 53, Luiss Lab of European Economics.

Egger, H. and P. Egger (2005), "Labor market effects of outsourcing under industrial interdependence", in International Review of Economics and Finance, Vol. 14, pp. 349-63.

Ekholm, K. and K. Hakkala (2006), "The Effect of Offshoring on Labor Demand: Evidence from Sweden", mimeo, Stockholm School of Economics and the Centre for Business and Policy Studies.

Falk, M. and Y. Wolfmayr (2005), "The Impact of International Outsourcing on Employment: Empirical Evidence from EU Countries", mimeo, Austrian Institute of Economic Research.

Federico, S. and G. A. Minerva (2005), "Fear of Relocation? Assessing the Impact of Italy's FDI on Local Employment", Quaderno No. 102/2005, Dept. of Economics and Quantitative Methods, University of Piemonte Orientale.

Feenstra, R.C. and G.H. Hanson (2003), "Global production sharing and rising inequality: a survey of trade and wages" in Handbook of International Trade, by E.K. Choi and J. Harrigan (eds.), Oxford, Basil-Blackwell. 
Feenstra, R. C. and G. H. Hanson (1996), "Globalization, Outsourcing, and Wage Inequality", in American Economic Review, Vol. 86, pp. 240-5.

Helpman, E., M. Melitz and S. Yeaple (2004), “Exports vs. FDI with heterogeneous firms", in The American Economic Review, Vol. 94, No. 1, pp. 300-16.

IMF (2007), World Economic Outlook- Spillovers and Cycles in the Global Economy, Washington.

Molnar, M., N. Pain and D. Taglioni (2007), "The Internationalisation of Production, International Outsourcing and Employment in the OECD", OECD Economics Department Working Papers, No. 561, OECD Publishing.

OECD (2007a), "Offshoring and employment: trend and policy implications", Directorate for Science, Technology and Industry, Working Party on Statistics.

OECD (2007b), "OECD workers in the global economy: increasingly vulnerable?", Directorate for Science, Technology and Industry, Working Party on Globalisation of Industry No. 12.

OECD (2006a), “The OECD Input-Output Database: 2006 Edition”, Statistical Analysis of Science, Technology and Industry Working Paper No. 2006/8.

OECD (2006b), "The share of employment potentially affected by offshoring - an empirical investigation", Directorate for Science, Technology and Industry, Working Party on the Information Economy No. 8.

OECD (2004), Employment Outlook.

OECD (2000), "The OECD Input-Output Database, Sources and Methods", mimeo, available via the web: www. oecd.org/dataoecd/48/43/2673344.pdf

Roodman, D. (2006), “How to Do xtabond2: An Introduction to "Difference" and "System" GMM in Stata", Center for Global Development Working Paper No. 103.

Schöller, D. (2007a), "Service Offshoring and the Demand for Less-Skilled Labor: Evidence from Germany", Working Paper No. 287/2007, University of Hohenheim.

Schöller, D. (2007b), "Service Offshoring: A Challenge for Employment? Evidence from Germany", CeGE Discussion Paper No. 61, University of Gottingen.

Van den Cruyce, B. (2004), "Use tables for imported goods and valuation matrices for trade margins. An integrated approach for the compilation of the Belgian 1995 Input-Output Tables", in Economic System Research, Vol. 16, pp. 33-61. 


\section{Appendix - Alternative measures of offshoring}

Formally, let $\mathbf{A}_{t}$ be the input output matrix at time $t$, and $\mathbf{F}_{\mathrm{t}}$ a similar matrix that contains only imported inputs; both square matrices have dimension $n$, with $n$ being the number of sectors. Assume that the matrices are structured so that the first $m$ sectors are manufacturing sectors, while the sectors between $m+1$ and $s$ are services sectors. The element $a_{t i j}$ of the matrix describes the use of goods $j$ by the sector that produces goods $i$ at time $t$, while the element $f_{\text {tij }}$ describes, at time $t$, the use of imported goods $\mathrm{j}$ by the sector that produces good i. Furthermore, let $\mathrm{y}_{\mathrm{ti}}$ and $\mathrm{v}_{\mathrm{ti}}$ be the domestic production and value added of sector $\mathrm{i}$ at time $\mathrm{t}$; we denote with $x_{t i}$ and $m_{t i}$ the exports and imports of the goods produced by the sector $i$.

A variety of measures of outsourcing has been employed in the empirical literature; the early contribution of Feenstra and Hanson $(1996,1999)$ did not have access to the $\mathbf{F}_{\mathrm{t}}$ matrix, so that they combined trade data with the information contained in the $\mathbf{A}_{t}$ matrix to derive the index of material offshoring $\mathrm{o}_{\mathrm{ti}}^{\mathrm{m}}$ :

$$
o_{t i}^{m}=\frac{\sum_{j=1}^{m} a_{t i j}\left(\frac{m_{t j}}{y_{t j}+m_{t j}-x_{t j}}\right)}{\sum_{j=1}^{s} a_{t i j}}
$$

The definition in [a1] rests on the import proportionality assumption, that is it implicitly assumes that the share of good $\mathrm{j}$ used as an input by each sector is equal to the economy-wide share of imports in domestic consumption. This definition has been recently used by Amiti and Wei (2005), who also proposed an analogous definition for an index $\mathrm{o}_{\mathrm{ti}}^{\mathrm{s}}$ of service offshoring:

$$
\mathrm{o}_{\mathrm{ti}}^{\mathrm{s}}=\frac{\sum_{\mathrm{j}=\mathrm{m}+1}^{\mathrm{s}} \mathrm{a}_{\mathrm{tij}}\left(\frac{\mathrm{m}_{\mathrm{tj}}}{\mathrm{y}_{\mathrm{tj}}+\mathrm{m}_{\mathrm{tj}}-\mathrm{x}_{\mathrm{tj}}}\right)}{\sum_{\mathrm{j}=1}^{\mathrm{s}} \mathrm{a}_{\mathrm{tij}}}
$$

Clearly, the import proportionality assumption is rather strict, as it does not leave room to any differences across sectors in the choice between domestically produced and imported inputs of any given good; the indices described in [a1] and [a2] are weighted averages of the import share in domestic consumption, with weights derived from the $\mathbf{A}_{\mathrm{t}}$ matrix that is the only factor that induces sectoral differences. Provided that one has access to the $\mathbf{F}_{\mathrm{t}}$ matrix, one can get rid of the import proportionality assumption, and define an index of offshoring that directly 
incorporates information on the actual share of imported inputs used by each sector.

Bracci (2006), Amiti and Ekholm (2006) and Schöller (2007a) rely on an index of service offshoring that replicates [a2], using the information contained in $\mathbf{F}_{\mathrm{t}}$ :

$$
\mathrm{O}_{\mathrm{ti}}^{\mathrm{s}}=\frac{\sum_{\mathrm{j}=\mathrm{m}+1}^{\mathrm{s}} \mathrm{f}_{\mathrm{tij}}}{\sum_{\mathrm{j}=1}^{\mathrm{s}} \mathrm{a}_{\mathrm{tij}}}
$$

Clearly, the superiority of [a3] over [a2] critically depends on the accuracy of the estimation of $\mathbf{F}_{\mathrm{t}}$, as the import of each good needs to be divided between final and intermediate uses, and the latter then need to be attributed to the various productive sectors. IMF (2007) claims that the three editions of the OECD input output tables - that are used in several empirical studies - build the $\mathbf{F}_{\mathrm{t}}$ matrices using the same "import proportionality assumption" that is incorporated in [a2]. Although the claim by IMF (2007) is incorrect, as the OECD input output tables reflect a huge variety of practises adopted by the statistical offices of its member states (see Bracci et al. 2006 for Italy, and Van den Cruyce 2004 for Belgium), it is nevertheless true that most countries adopt the "import proportionality assumption" at a rather crude level of aggregation to build their $\mathbf{F}_{t}$ matrix, as evidenced by Bracci (2006). OECD (2000) reports that Germany and Denmark apply the "import proportionality assumption" to a fine disaggregation of products, that comprises more than 2000 goods, while this figure reduces to around 500 for Japan and the United States, and below 200 for the United Kingdom. As the ISTAT produces Italian $\mathbf{F}_{\mathrm{t}}$ matrices using practises that substantially improve on the import proportionality assumptions, it should come as little surprise that - as Daveri and Jona-Lasinio (2007) instead emphasize - the indices in [a2] and [a3] can provide significantly diverging estimates of offshoring.

Some authors - as Egger and Egger (2005) and Bracci (2006) - also rely on a narrowly defined index of offshoring - that can be indifferently applied to manufacturing or service sectors - that is given by the ratio of the diagonal elements of the matrices $\mathbf{F}_{\mathrm{t}}$ and $\mathbf{A}_{\mathrm{t}}$ :

$\mathrm{o}_{\mathrm{ti}}^{\text {narrow }}=\frac{\mathrm{f}_{\mathrm{tii}}}{\mathrm{a}_{\mathrm{tii}}}$ 
Ekholm and Hakkala (2006) adopt an alternative measure of offshoring $\mathrm{O}_{\mathrm{ti}}$ - that encompasses both manufactured goods and services - that uses information drawn from the $\mathbf{F}_{\mathrm{t}}$ matrix:

$\mathrm{o}_{\mathrm{ti}}=\frac{\sum_{\mathrm{j}=1}^{\mathrm{s}} \mathrm{f}_{\mathrm{tij}}}{\mathrm{y}_{\mathrm{ti}}}$

Note that the index described in [a5] can be expressed as the product of an index defined as in Bracci (2006) times the ratio of total inputs over sectoral production, so that this index will be always lower than indices built as in [a3]. The same can be said about the index employed in OECD (2007b), that divides the total costs of imported inputs by the value added of each sector:

$\mathrm{o}_{\mathrm{ti}}=\frac{\sum_{\mathrm{j}=1}^{\mathrm{s}} \mathrm{f}_{\mathrm{tij}}}{\mathrm{v}_{\mathrm{ti}}}$ 
Table 1. Definition of the variables and data sources

\section{Variable}

Employment, $\ln \left(e_{i t}\right)$

Real wage, $\ln \left(w_{i t}\right)$

Capital stock, $\ln \left(k_{i t}\right)$

Real output, $\ln \left(q_{i t}\right)$

Real Price, $\ln \left(p_{i t}\right)$

Import share, $\ln \left(m_{\text {itt }}\right)$

$R \& D$ intensity, $\ln \left(r_{\mathrm{it}}\right)$

Material offshoring, $\ln \left(\mathrm{O}_{\mathrm{ti}}^{\mathrm{m}}\right)$

Material offshoring,

narrow, $\ln \left(\mathrm{O}_{\mathrm{ti}}^{\mathrm{m}, \mathrm{n}}\right)$

Material offshoring, external, $\ln \left(\mathrm{O}_{\mathrm{ti}}^{\mathrm{m}, \mathrm{e}}\right)$
Definition

Log of total persons engaged, full-time equivalent

Log of total labour costs divided by total persons engaged in full-time equivalent unit, over the price index of material inputs.

Log of the capital stock at 2000 constant prices

Log of the output at 2000 constant prices

Log of the implicit value added deflator

Log of imports for final uses over final uses of a good

Log of the R\&D expenditure over the sectoral value added

Log of the imports of manufactured goods over total costs for manufactured inputs

Log of the share of imported input from the same sector

Log of imported inputs by other sectors over sectoral demand

\section{Source}

OeCD STAN Database

OECD STAN Database and ISTAT

Tavole Input Output

ISTAT Conti Economici Nazionali

OECD STAN Database and ISTAT Tavole Input Output

ISTAT Conti Economici Nazionali

ISTAT Tavole Input Output

OeCD STAN Database and OECD ANBERD Database

ISTAT Tavole Input Output

ISTAT Tavole Input Output

ISTAT Tavole Input Output

Table 2. Unit of analysis

\section{Sectors, Description}

I SIC codes

15-16 Food products, beverages and tobacco

17-18 Textiles and textile products

19 Leather and footwear

$20 \quad$ Wood and products of wood and cork

21-22 Pulp, paper, paper products, printing and publishing

23 Coke, refined petroleum products and nuclear fuel

$24 \quad$ Chemicals

$25 \quad$ Rubber and plastic products

$26 \quad$ Other non-metallic mineral products

27-28 Iron and steel, non ferrous metals and fabricated metal products, except machinery and equipment

$29 \quad$ Machinery and equipment

30-33 Office, accounting and computing machinery, electrical machinery and apparatus, radio, television and communication equipment, medical, precision and optical instrument

34-35 Motor vehicles, trailers and semi-trailers and other transport equipment 
Figure 1a. ISIC 15-16, Food products, beverages and tobacco

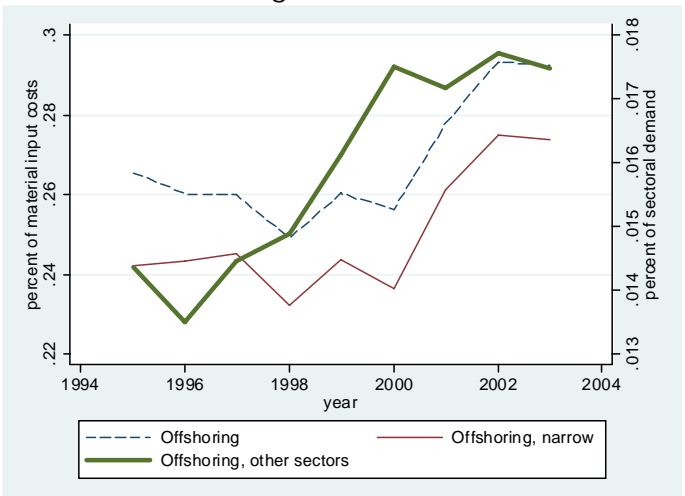

Figure 1b. ISIC 17-18, Textiles and textile products

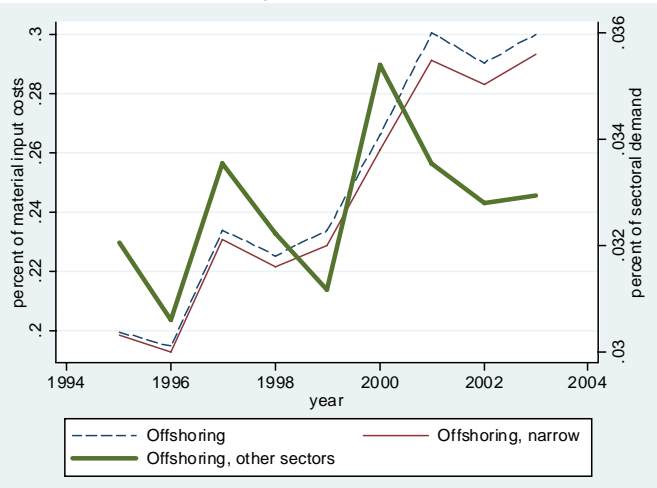

Figure 1c. ISIC 19, Leather and footwear

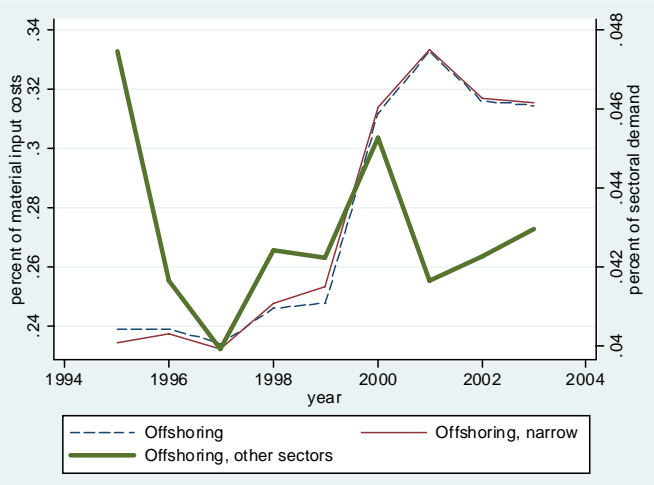

Figure 1d. ISIC 20, Wood and products of wood and cork

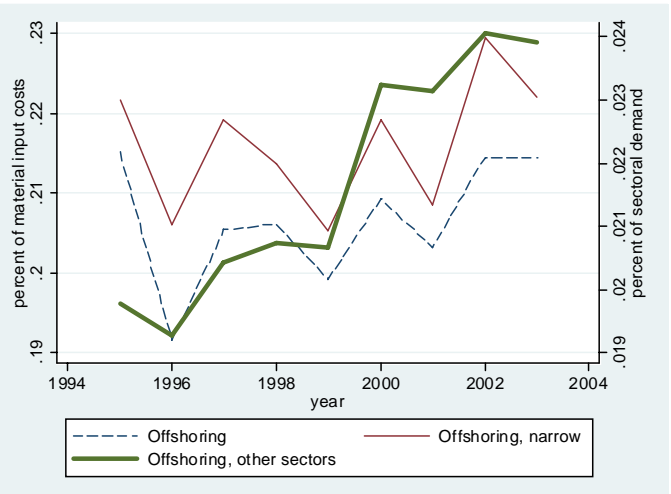

Figure 1e. ISIC 21-22, Pulp, paper, paper products, printing and publishing

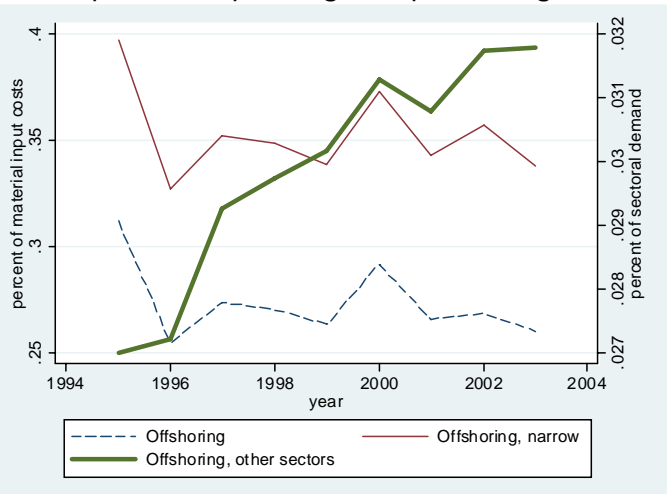

Figure 1f. ISIC 23, Coke, refined petroleum products and nuclear fuel

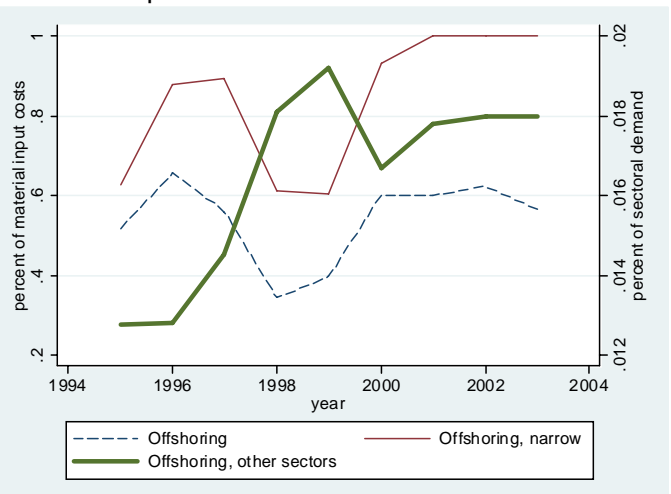

Figure 1g. IsıC 24, Chemicals

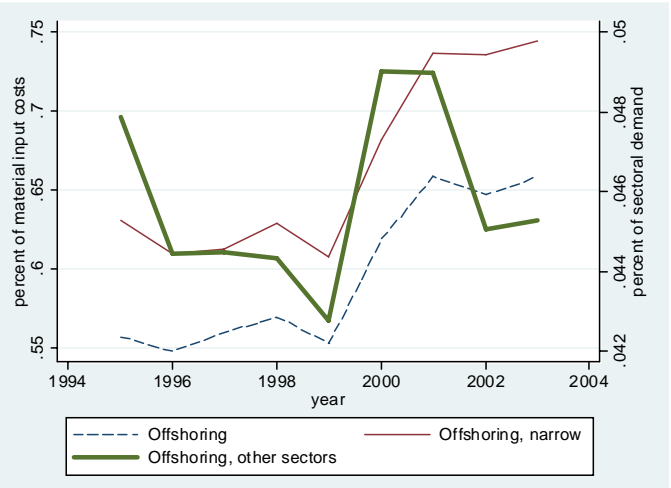

Figure 1h. ISIC 25, Rubber and plastic products

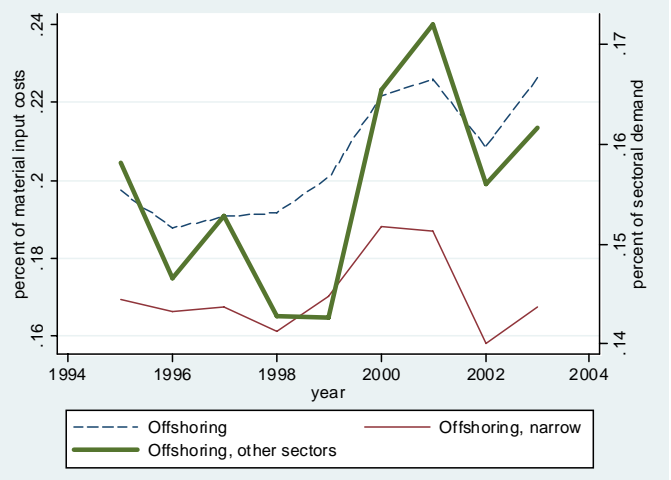


Figure 1i. ISIC 26, Other non-metallic mineral products

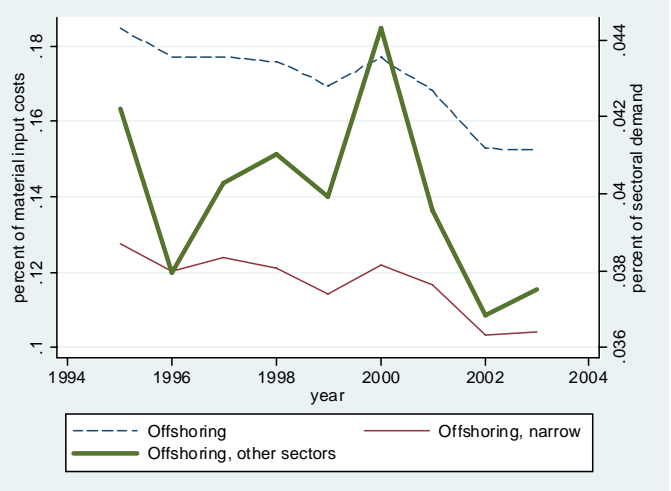

Figure 1j. ISIC 27-28, I ron and steel, non ferrous metals and fabricated metal products, except machinery and equipment

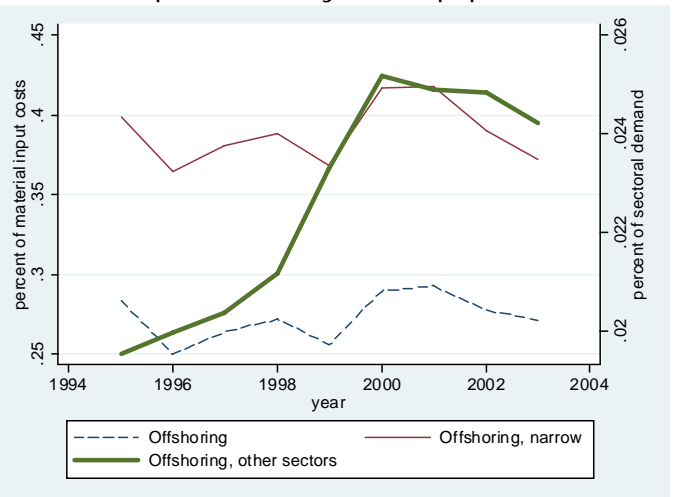

Figure 1k. ISIC 29, Machinery and equipment

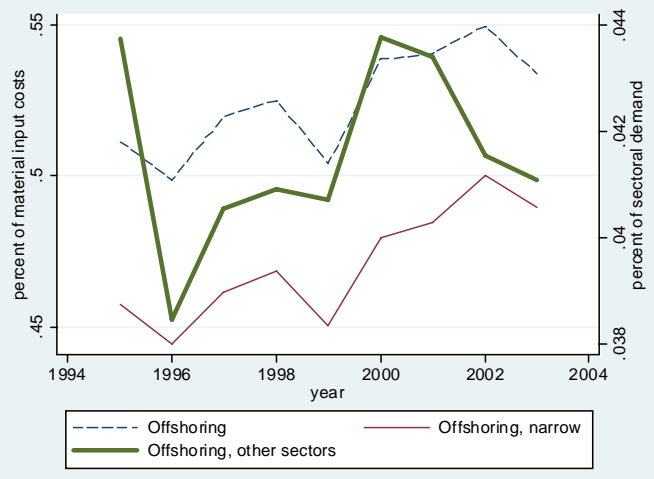

Figure 1I. ISIC 30-33, Office, accounting and computing machinery, electrical machinery and apparatus, radio, television and communication equipment, medical, precision and optical instrument

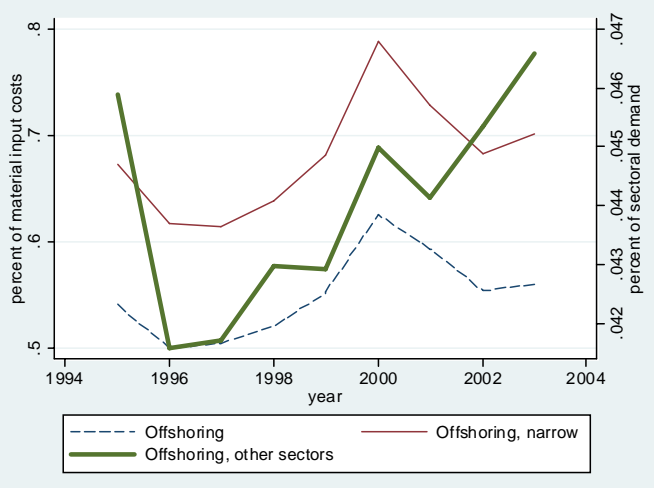

Figure $1 \mathbf{m}$. ISIC 34-35, Motor vehicles, trailers and semi-trailers and other transport equipment

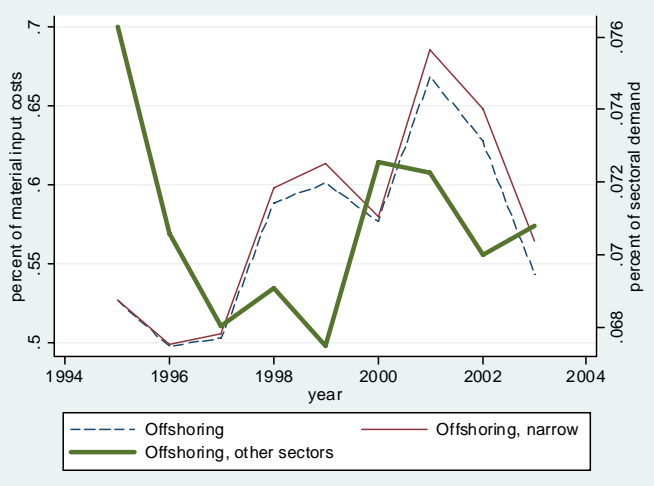

Figure 1n. ISIC 36-37, Manufacturing nec; recycling (including furniture)

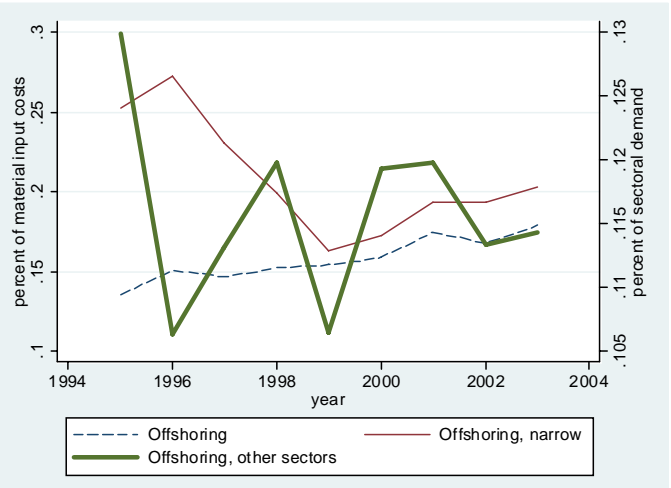


Table 3. Descriptive statistics, 1995-2003

\begin{tabular}{|c|c|c|c|c|c|c|c|c|c|c|c|c|c|c|c|c|}
\hline \multirow[b]{2}{*}{$\begin{array}{l}\text { Sector, } \\
\text { ISIC codes }\end{array}$} & \multicolumn{2}{|c|}{ Employment } & \multicolumn{2}{|c|}{ Outsourcing } & \multicolumn{2}{|c|}{$\begin{array}{l}\text { Outsourcing, } \\
\text { narrow }\end{array}$} & \multicolumn{2}{|c|}{$\begin{array}{c}\text { Outsourcing, } \\
\text { external }\end{array}$} & \multicolumn{2}{|c|}{$\begin{array}{l}\text { I mports, final } \\
\text { goods }\end{array}$} & \multicolumn{2}{|c|}{$\begin{array}{c}\text { R\&D over value } \\
\text { added }\end{array}$} & \multirow{2}{*}{$\begin{array}{c}\text { Wage } \\
\text { growth rate }\end{array}$} & \multirow{2}{*}{$\begin{array}{l}\text { Capital } \\
\text { growth rate }\end{array}$} & \multirow{2}{*}{$\begin{array}{l}\text { Output } \\
\text { growth rate }\end{array}$} & \multirow{2}{*}{$\begin{array}{c}\text { Price } \\
\text { growth rate }\end{array}$} \\
\hline & $\begin{array}{l}\text { average } \\
(000 s)\end{array}$ & $\begin{array}{l}\text { growth } \\
\text { rate }\end{array}$ & $\begin{array}{c}\text { average } \\
\text { (percent) }\end{array}$ & $\begin{array}{l}\text { average } \\
\text { (percent) }\end{array}$ & growth rate & $\begin{array}{l}\text { growth } \\
\text { rate }\end{array}$ & $\begin{array}{l}\text { average } \\
\text { (percent) }\end{array}$ & growth rate & $\begin{array}{c}\text { average } \\
\text { (percent) }\end{array}$ & $\begin{array}{l}\text { growth } \\
\text { rate }\end{array}$ & $\begin{array}{c}\text { average } \\
\text { (percent) }\end{array}$ & growth rate & & & & \\
\hline $15-16$ & 476.1 & 0.23 & 26.82 & 1.21 & 25.02 & 1.54 & 1.59 & 2.48 & 13.10 & -0.01 & 0.38 & 1.74 & -0.06 & 2.47 & -0.54 & 3.33 \\
\hline $17-18$ & 733.9 & -2.32 & 24.95 & 5.22 & 24.47 & 5.00 & 3.27 & 0.34 & 8.40 & 1.67 & 0.15 & 17.26 & 2.29 & 0.39 & -1.42 & 2.30 \\
\hline 19 & 216.9 & -2.14 & 27.56 & 3.49 & 27.59 & 3.78 & 4.29 & -1.23 & 7.83 & 7.40 & 0.13 & 8.11 & 0.30 & 1.59 & -4.16 & 3.81 \\
\hline 20 & 193.6 & -0.38 & 20.65 & -0.04 & 21.60 & 0.03 & 2.17 & 2.41 & 3.75 & 3.22 & 0.09 & -4.77 & 2.12 & 0.40 & 2.70 & 0.87 \\
\hline 21-22 & 298.1 & 0.64 & 27.34 & -2.24 & 35.27 & -1.99 & 2.99 & 2.06 & 4.38 & 1.21 & 0.12 & 9.11 & -0.26 & 4.67 & 0.28 & 2.30 \\
\hline 23 & 25.0 & 0.00 & 54.01 & 1.15 & 83.77 & 6.01 & 1.64 & 4.40 & 0.12 & -3.43 & 0.85 & -14.06 & 2.40 & 2.62 & 8.05 & -3.18 \\
\hline 24 & 231.6 & 0.44 & 59.67 & 2.10 & 66.54 & 2.08 & 4.58 & -0.69 & 8.05 & 4.37 & 4.64 & -0.72 & 1.56 & 0.96 & 0.73 & 1.42 \\
\hline 26 & 317.2 & 2.88 & 17.05 & -2.39 & 11.71 & -2.50 & 3.99 & -1.45 & 4.48 & 1.06 & 0.22 & 9.77 & 0.10 & 3.12 & 2.71 & 2.31 \\
\hline $27-28$ & 755.0 & 0.87 & 27.29 & -0.56 & 38.85 & -0.88 & 2.26 & 2.73 & 3.01 & 1.29 & 0.34 & -3.81 & 1.17 & 2.43 & 0.92 & 0.76 \\
\hline 29 & 544.6 & 1.17 & 52.46 & 0.54 & 47.08 & 0.86 & 4.16 & -0.76 & 9.45 & 0.49 & 2.05 & 10.41 & 0.73 & 1.33 & 0.64 & 2.40 \\
\hline $30-33$ & 463.8 & 0.76 & 55.04 & 0.43 & 68.02 & 0.52 & 4.40 & 0.19 & 26.93 & 2.76 & 7.87 & -2.12 & 0.92 & 3.26 & -0.10 & 1.39 \\
\hline 34-35 & 281.7 & -1.49 & 57.05 & 0.38 & 58.02 & 0.86 & 7.08 & -0.93 & 38.25 & 4.68 & 10.46 & -1.87 & -0.30 & -0.09 & -0.20 & 3.21 \\
\hline $36-37$ & 307.3 & -0.31 & 15.77 & 3.55 & 20.88 & -2.70 & 11.58 & -1.58 & 7.20 & 2.78 & 0.26 & 9.35 & 2.02 & 1.17 & 0.72 & 1.92 \\
\hline
\end{tabular}

Note: average yearly growth rates are computed over the period 1995-2003 
Table 4. Correlation matrix

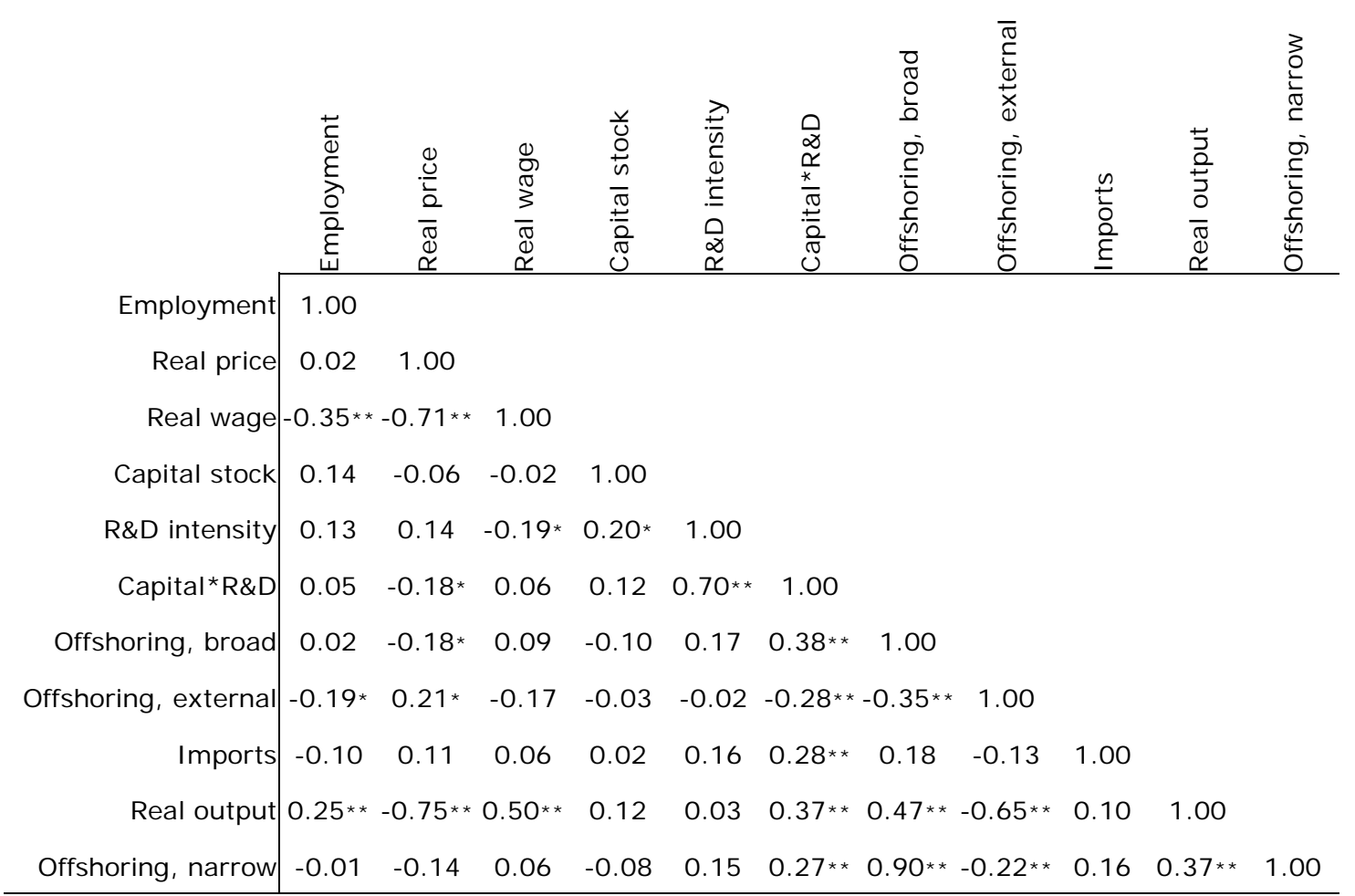

Note: the variables are defined as described in Table 1; correlations have been computed after subtracting a year-specific and a sector-specific variable; $* *$ and $*$ denote significance at the 1 and 5 percent confidence level respectively. 
Table 5. Estimates of the conditional and unconditional labor demand

\begin{tabular}{|c|c|c|c|c|c|c|c|c|c|c|c|c|}
\hline \multirow{4}{*}{ Specification } & \multicolumn{12}{|c|}{$\Delta$ employment } \\
\hline & \multicolumn{6}{|c|}{ Conditional labor demand } & \multicolumn{6}{|c|}{ Unconditional labor demand } \\
\hline & (1) & $(2)$ & (3) & (4) & (5) & (6) & (7) & (8) & (9) & (10) & (11) & (12) \\
\hline & $\begin{array}{c}\text { coefficient } \\
\text { (t-test) }\end{array}$ & $\begin{array}{c}\text { coefficient } \\
\text { (t-test) }\end{array}$ & $\begin{array}{c}\text { coefficient } \\
\text { (t-test) }\end{array}$ & $\begin{array}{c}\text { coefficient } \\
\text { (t-test) }\end{array}$ & $\begin{array}{c}\text { coefficient } \\
\text { (t-test) }\end{array}$ & $\begin{array}{c}\text { coefficient } \\
\text { (t-test) }\end{array}$ & $\begin{array}{c}\text { coefficient } \\
\text { (t-test) }\end{array}$ & $\begin{array}{c}\text { coefficient } \\
\text { (t-test) }\end{array}$ & $\begin{array}{c}\text { coefficient } \\
\text { (t-test) }\end{array}$ & $\begin{array}{c}\text { coefficient } \\
\text { (t-test) }\end{array}$ & $\begin{array}{c}\text { coefficient } \\
\text { (t-test) }\end{array}$ & $\begin{array}{c}\text { coefficient } \\
\text { (t-test) }\end{array}$ \\
\hline$\Delta$ Real wage & $\begin{array}{c}-0.693 \\
(-6.80) * * *\end{array}$ & $\begin{array}{c}-0.819 \\
(-9.91) * * *\end{array}$ & $\begin{array}{c}-0.689 \\
(-13.14)^{* * *}\end{array}$ & $\begin{array}{c}-0.717 \\
(-11.87)^{* * *}\end{array}$ & $\begin{array}{c}-0.705 \\
(-12.16) * * *\end{array}$ & $\begin{array}{c}-0.689 \\
(-10.91)^{* * *}\end{array}$ & $\begin{array}{c}-0.765 \\
(-3.52) * * *\end{array}$ & $\begin{array}{c}-0.691 \\
(-6.26) * * *\end{array}$ & $\begin{array}{c}-0.809 \\
(-7.81) * * *\end{array}$ & $\begin{array}{c}-0.863 \\
(-7.93)^{* * *}\end{array}$ & $\begin{array}{c}-0.842 \\
(-8.26) * * *\end{array}$ & $\begin{array}{c}-0.961 \\
(-7.43) * * *\end{array}$ \\
\hline$\Delta$ Capital stock & $\begin{array}{l}0.128 \\
(0.88)\end{array}$ & $\begin{array}{l}0.103 \\
(0.81)\end{array}$ & $\begin{array}{l}0.066 \\
(0.77)\end{array}$ & $\begin{array}{l}0.036 \\
(0.36)\end{array}$ & $\begin{array}{l}0.071 \\
(0.72)\end{array}$ & $\begin{array}{l}0.132 \\
(1.23)\end{array}$ & $\begin{array}{l}0.222 \\
(1.24)\end{array}$ & $\begin{array}{l}0.151 \\
(1.15)\end{array}$ & $\begin{array}{c}0.214 \\
(2.32) * *\end{array}$ & $\begin{array}{c}0.236 \\
(2.46) * *\end{array}$ & $\begin{array}{c}0.184 \\
(1.78) * *\end{array}$ & $\begin{array}{c}0.212 \\
(2.09) * *\end{array}$ \\
\hline$\Delta R \& D$ intensity & $\begin{array}{c}0.019 \\
(3.24) * * *\end{array}$ & $\begin{array}{c}0.018 \\
(2.75)^{* * *}\end{array}$ & $\begin{array}{c}0.022 \\
(5.18)^{* * *}\end{array}$ & $\begin{array}{c}0.020 \\
(4.14)^{* * *}\end{array}$ & $\begin{array}{c}0.016 \\
(3.12)^{* * *}\end{array}$ & $\begin{array}{c}0.009 \\
(2.06)^{* *}\end{array}$ & $\begin{array}{c}0.023 \\
(2.75) * * *\end{array}$ & $\begin{array}{c}0.026 \\
(3.78) * * *\end{array}$ & $\begin{array}{c}0.026 \\
(3.98) * * *\end{array}$ & $\begin{array}{c}0.027 \\
(3.93) * * *\end{array}$ & $\begin{array}{c}0.025 \\
(3.74) * * *\end{array}$ & $\begin{array}{c}0.009 \\
(1.75) *\end{array}$ \\
\hline$\Delta R \& D$ intens. $* \Delta$ Cap. stock & $\begin{array}{c}-0.698 \\
(-2.29)^{* *}\end{array}$ & $\begin{array}{c}-0.749 \\
(-2.39) * *\end{array}$ & $\begin{array}{c}-0.820 \\
(-4.10) * * *\end{array}$ & $\begin{array}{c}-0.724 \\
(-3.25)^{* * *}\end{array}$ & $\begin{array}{c}-0.474 \\
(-2.04) * *\end{array}$ & $\begin{array}{l}-0.029 \\
(-0.15)\end{array}$ & $\begin{array}{c}-0.963 \\
(-2.46) * *\end{array}$ & $\begin{array}{c}-1.079 \\
(-3.33) * * *\end{array}$ & $\begin{array}{c}-0.996 \\
(-3.46) * * *\end{array}$ & $\begin{array}{c}-1.023 \\
(-3.54) * * *\end{array}$ & $\begin{array}{c}-0.850 \\
(-2.75) * * *\end{array}$ & $\begin{array}{l}-0.112 \\
(-0.47)\end{array}$ \\
\hline$\Delta$ Real output & $\begin{array}{c}0.381 \\
(6.56) * * *\end{array}$ & $\begin{array}{c}0.386 \\
(8.32)^{* * *}\end{array}$ & $\begin{array}{c}0.340 \\
(9.27)^{* * *}\end{array}$ & $\begin{array}{c}0.344 \\
(8.91)^{* * *}\end{array}$ & $\begin{array}{c}0.311 \\
(8.30)^{* * *}\end{array}$ & $\begin{array}{c}0.334 \\
(8.16) * * *\end{array}$ & - & - & - & - & - & - \\
\hline$\Delta$ Real price & - & - & - & - & - & - & $\begin{array}{c}-0.357 \\
(-2.38) * *\end{array}$ & $\begin{array}{c}-0.306 \\
(3.21) * * *\end{array}$ & $\begin{array}{c}-0.359 \\
(-4.69) * * *\end{array}$ & $\begin{array}{c}-0.396 \\
(-4.84) * * *\end{array}$ & $\begin{array}{c}-0.366 \\
(-4.24) * * *\end{array}$ & $\begin{array}{c}-0.442 \\
(-4.55)^{* * *}\end{array}$ \\
\hline$\Delta$ Material offshoring & $\begin{array}{c}-0.048 \\
(-1.98) *\end{array}$ & $\begin{array}{c}-0.043 \\
(-1.75) *\end{array}$ & $\begin{array}{c}-0.033 \\
(-2.00)^{* *}\end{array}$ & $\begin{array}{c}-0.047 \\
(-2.66)^{* * *}\end{array}$ & $\begin{array}{c}-0.036 \\
(-1.93) *\end{array}$ & $\begin{array}{l}-0.032 \\
(-1.52)\end{array}$ & $\begin{array}{l}-0.022 \\
(-0.62)\end{array}$ & $\begin{array}{l}-0.022 \\
(-0.85)\end{array}$ & $\begin{array}{l}-0.024 \\
(-1.11)\end{array}$ & $\begin{array}{l}-0.025 \\
(-1.10)\end{array}$ & $\begin{array}{l}-0.007 \\
(-0.31)\end{array}$ & $\begin{array}{l}-0.015 \\
(-0.59)\end{array}$ \\
\hline$\Delta_{(\mathrm{t}-1)}$ Material offshoring & - & - & - & - & $\begin{array}{l}0.020 \\
(1.03)\end{array}$ & - & - & - & - & - & $\begin{array}{l}0.018 \\
(0.79)\end{array}$ & - \\
\hline$\Delta$ Material offshor., ext. & $\begin{array}{l}0.067 \\
(1.34)\end{array}$ & $\begin{array}{c}0.069 \\
(1.67) *\end{array}$ & $\begin{array}{c}0.051 \\
(1.53)\end{array}$ & $\begin{array}{l}0.051 \\
(1.41)\end{array}$ & $\begin{array}{l}0.020 \\
(0.54)\end{array}$ & $\begin{array}{c}0.075 \\
(1.77) *\end{array}$ & $\begin{array}{c}-0.130 \\
(-2.59) * *\end{array}$ & $\begin{array}{c}-0.179 \\
(-4.95)^{* * *}\end{array}$ & $\begin{array}{c}-0.109 \\
(-3.67) * * *\end{array}$ & $\begin{array}{c}-0.113 \\
(-3.51)^{* * *}\end{array}$ & $\begin{array}{c}-0.165 \\
(-5.51)^{* * *}\end{array}$ & $\begin{array}{c}-0.128 \\
(-3.33) * * *\end{array}$ \\
\hline$\Delta_{(\mathrm{t}-1)}$ Material offshor., ext. & - & - & - & - & $\begin{array}{c}0.032 \\
(1.15)\end{array}$ & - & - & - & - & - & $\begin{array}{l}0.033 \\
(1.11)\end{array}$ & - \\
\hline$\Delta \mathrm{lmport}$ & $\begin{array}{c}-0.015 \\
(-2.90)^{* * *}\end{array}$ & $\begin{array}{c}-0.013 \\
(-1.48) * * *\end{array}$ & $\begin{array}{c}-0.014 \\
(-2.18) * *\end{array}$ & $\begin{array}{c}-0.015 \\
(-2.18) * *\end{array}$ & $\begin{array}{c}-0.015 \\
(-2.62) * * *\end{array}$ & $\begin{array}{c}-0.016 \\
(-2.17) * *\end{array}$ & $\begin{array}{l}-0.011 \\
(-1.67) *\end{array}$ & $\begin{array}{l}-0.012 \\
(-1.32)\end{array}$ & $\begin{array}{l}-0.011 \\
(-1.57)\end{array}$ & $\begin{array}{l}-0.010 \\
(-1.38)\end{array}$ & $\begin{array}{c}-0.012 \\
(-1.88) *\end{array}$ & $\begin{array}{l}-0.010 \\
(-1.17)\end{array}$ \\
\hline Number of observations & 104 & 104 & 104 & 104 & 91 & 91 & 104 & 104 & 104 & 104 & 91 & 91 \\
\hline Number of sectors & 13 & 13 & 13 & 13 & 13 & 13 & 13 & 13 & 13 & 13 & 13 & 13 \\
\hline Lag, number of years & 1 & 1 & 1 & 1 & 1 & 2 & 1 & 1 & 1 & 1 & 1 & 2 \\
\hline Sectoral dummies & - & yes & yes & yes & yes & yes & - & yes & yes & yes & yes & yes \\
\hline Year dummies & yes & yes & yes & yes & yes & yes & yes & yes & yes & yes & yes & yes \\
\hline Estimation technique & $\mathrm{FE}$ & robust regr. & FGLS & FGLS & FGLS & FGLS & FE & robust regr. & FGLS & FGLS & FGLS & FGLS \\
\hline Heteroskedasticity & - & - & yes & yes & yes & yes & - & - & yes & yes & yes & yes \\
\hline Serial correlation & - & - & $\operatorname{psAR}(1)$ & $\mathrm{AR}(1)$ & $\mathrm{AR}(1)$ & $\mathrm{AR}(1)$ & - & - & $\operatorname{psAR}(1)$ & $\mathrm{AR}(1)$ & $\mathrm{AR}(1)$ & $\mathrm{AR}(1)$ \\
\hline
\end{tabular}

